Original Articles

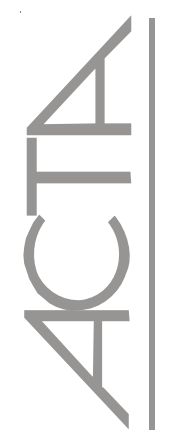

\title{
Being an HIV-positive mother: meanings for HIV-positive women and for professional nursing staff*
}

\author{
Ser-mãe HIV-positivo: significados para mulheres HIV-positivo e para a enfermagem \\ Ser-madre HIV-positivo: significados para las mujeres HIV-positivo y para la enfermería \\ Marisa Monticelli', Evanguelia Kotzias Atherino dos Santos ${ }^{2}$, Alacoque \\ Lorenzini Erdmann ${ }^{3}$
}

\begin{abstract}
Objectives: To comprehend the meanings of being an HIV-positive mother for HIV-positive women and for professional nursing staff of shared in-patient maternity wards, and to identify similarities and contrasts present in these meanings. Methods: This was a descriptive and comparative secondary analysis study of data from two previous larger studies conducted in Public Hospitals of the Greater Florianopolis Area, Santa Catarina, Brazil. Data was collected through observation and interviews. Results: For HIV-positive women the main meaning of being an HIV-positive mother was being a "super-mom" while for professional nursing staff the meaning was being "resistant." The meaning of being super-mom focuses on the motherhood role, which may be incompatible with the condition of carrier of the HIV virus. The meaning of being resistant does not fit with the experience of being mother. Conclusion: The meanings attributed by HIV-positive women, compared to those attributed by professional nursing staff, suggest prejudice, social stigma, and symbolic vulnerability.

Descritores: Acquired immunodeficiency syndrome; Nursing care; Rooming-in care; Mother-child relations; HIV
\end{abstract}

\section{RESUMO}

Objetivo: Compreender os significados de ser-mãe HIV positivo para mulheres HIV positivo e para trabalhadoras de enfermagem de unidades de alojamento conjunto e identificar as similaridades e contrastes presentes nesses significados. Métodos: Estudo descritivo e comparado, que utilizou dados de duas investigações anteriores, desenvolvidas em unidades de alojamento conjunto de maternidades públicas da Grande Florianópolis, SC, coletados por meio de observações participantes e entrevistas. Resultados: Para as mulheres HIV positivo, essas mulheres são "mãezonas" e para as trabalhadoras de enfermagem, essas mulheres são "resistentes". Isto evidencia certas representações relativas ao papel materno, como sendo absolutamente incompatíveis com a condição de portadoras do vírus. Para a enfermagem, o fato de a puérpera ser HIV positivo não "combina” com a experiência de ser mãe. Conclusão: Os significados atribuídos pelas mulheres HIV positivo, ao serem aproximados das percepções das trabalhadoras de enfermagem, revelam-se fortemente impregnados de preconceito, estigma social e vulnerabilidade simbólica.

Descritores: Síndrome de imunodeficiência adquirida; Cuidados de enfermagem; Alojamento conjunto; Relações mãe-filho; HIV

\section{RESUMEN}

Objetivo: comprender los significados de ser-madre VIH positivo para mujeres VIH positivo y para trabajadoras de enfermería de unidades de alojamiento conjunto e identificar las similitudes y contrastes presentes en esos significados. Métodos: estudio descriptivo y comparado, en el que se utilizó datos de dos investigaciones anteriores, desarrolladas en unidades de alojamiento conjunto de maternidades públicas de la Gran Florianópolis, (Santa Catarina-Brasil), recolectados por medio de observaciones participantes y entrevistas. Resultados: para las mujeres VIH positivo, esas mujeres son "mamazonas" y para las trabajadoras de enfermería, esas mujeres son "resistentes", evidenciándose ciertas representaciones relativas al papel materno, como absolutamente incompatibles con la condición de portadoras del virus. Para la enfermería, el hecho de que la puérpera sea VIH positivo no "combina" con la experiencia de ser madre. Conclusión: los significados atribuidos por las mujeres VIH positivo, al ser aproximados a las percepciones de las trabajadoras de enfermería, se revelan fuertemente impregnados de prejuicios, estigma social y vulnerabilidad simbólica.

Descriptores: Síndrome de la inmunodeficiencia adquirida; Cuidado de enfermería; Alojamiento conjunto; Relaciones Madre-Hijo; HIV

* Study carried out in a Public Maternity Hospital in Florianópolis.

${ }^{1}$ DNS; Associate Professor at the University of Santa Catarina (UFSC) - Nursing Department and Graduate Nursing Program; Florianopolis (SC), Brazil;

${ }^{2}$ DNS; Associate Professor at the University of Santa Catarina (UFSC) - Nursing Department and Graduate Nursing Program; Florianopolis (SC), Brazil;

${ }^{3}$ Full Professor At the University of Santa Catarina (UFSC) - Nursing Department and Graduate Nursing Program; Florianopolis (SC), Brazil. 


\section{ITRODUCTION}

Since Acquired Immunodeficiency Syndrome (AIDS) and Human Immunodeficiency Virus (HIV) appeared, the estimates presented in the Joint United Nations program on AIDS/HIV indicate there is an overall rising tendency for the transmission of this virus. Women, in particular, currently represent $50 \%$ of the global epidemic. In fact, in some African countries, the rate is approximately $58 \%$. In Latin America, the number of HIV-infected children and adults has increased and is currently 1.6 million. About one third of Latin American HIV-positivepopulation live in Brazil, and efforts have been made to stop this epidemic ${ }^{(1)}$.

In Brazil, the first AIDS case was identified in 1980. Since that date, and until June 2006, 430,000 new cases have been notified, of which $62.3 \%$ live in the Southeast, $17.9 \%$ in the South, $11 \%$ in the Northeast, $5.6 \%$ in the Central-West, and $3.2 \%$ in the North. The South region has the highest incidence rates, whereas the Southeast is currently undergoing a stabilization process. The gender relation continues reducing gradually, and is currently 15 men for 10 women $(1.5 \mathrm{H}: \mathrm{M})$. Regarding pregnant women, from the year 2000 to $11 / 30 / 2006$, there were 31,921 notified cases. In Santa Catarina, 16,960 cases had been reported until 2005 , corresponding to 16,142 adults and 818 children ( $92.3 \%$ by vertical transmission). Of this total, 5,638 were notified in women ${ }^{(2-3)}$.

This female population has sought their right to quality care, including welcoming, access, surveillance, individual care, and availability ${ }^{(4)}$. Moreover, studies have reported that HIV-positive pregnant and postpartum women participating in pre-natal programs or hospitalized in maternities, seek more than therapeutic solutions for their physical signs and symptoms. They also want to find people who would welcome them and consider them human beings, who "understand" them and their multiple dimensions as women and mothers with particular and different characteristics ${ }^{(5-7)}$. A Brazilian study about the meanings assigned by HIV-positive women-mothers brings to light the interpretation that "being a mother" and "having AIDS" represents a process that transcends the disease. This process is associated with the polarity between good and evil, involving dualist values impregnated of sacred notions regarding motherhood as well as profane notions regarding sexuality ${ }^{(8)}$.

From a different perspective, nurses and faculty note there are numerous demands for care in rooming-in wards, mainly concerning the feelings that "new-mothers" report regarding their inability to breastfeed. This requires sensitivity and special handling, which, in turn, demands skills and abilities that are sometimes not performed with the necessary safety and knowledge by the staff. Nurses, in this care situation, are frequently unaware of the real needs and meanings related with the event. They also state insecurities regarding the actions that should be put into practice in order to provide more than just health care. It is noticed that there usually are diverse meanings between women and nurses, perhaps due to the values of being a mother, being HIV-positive, and not being able to breastfeed, among others.

Two recent studies, performed in the same health care environment, one with HIV-positive women ${ }^{(7)}$, and the other with nurses ${ }^{(9)}$, showed there are entwined similarities and differences regarding the form this experience takes place. This permits to reflect on the meanings that permeate these relationships in the hospital setting. The results of both studies were the basis for formulating the following questions used in the present study: what is the meaning of being an HIV-positive mother for HIVpositive women, and for nurses at a rooming-in ward? What are the similarities and differences regarding these meanings?

Based on these guiding questions, the study purpose was outlined: to understand the meanings of being an HIV-positive mother for HIV-positive women, and for nurses at rooming-in wards, as well as to identify the similarities and contrasts regarding these meanings.

\section{METHODS}

This is a descriptive and comparative research, founded on two studies performed with different method approaches. The first, inspired by interpretative phenomenology, revealed the meanings that HIV-positive postpartum women assign to their existence as women/ mothers. The second, inspired by ethnography, shed light on the meanings that nurses have regarding these women/mothers, in rooming-in units. Both studies had the same research purpose and data were collected in the same location. Subjects described what made sense to them regarding the investigated phenomena, as well as how the phenomena were perceived and reported by means of language and other forms of expression.

The comparative method used was based on these two studies, considered data maps or metadata ${ }^{(10)}$. The studies' similarities and contrasts provided plausible answers to the research questions. Despite the different methodological frameworks (interpretative phenomenology and ethnography), it is understood that the comparison is feasible, since this "triangulation" helps to shed light on the interpretation regarding the studied phenomenon, taking participants into consideration, in terms of their cultural background, and everyday experiences. The combination of methodological research approaches, especially ethnography and interpretative phenomenology, increases the potential of the several facets involved in the studied reality, since both have 
several aspects in common ${ }^{(10)}$.

Hence, the data map was carefully read, with a view to comparing similarities and contrasts in the studies. In the first study ${ }^{(7)}$ the sample consisted of 24 women/ mothers who experienced the situation of not being able to breastfeed because they were HIV-positive. The second study ${ }^{(9)}$ involved 19 nurses who cared for HIV-positive women during their postpartum period. While in the first study the researcher remained in the setting (rooming-in units in public maternity hospitals in Greater Florianopolis) for five months (July 9 to November 30, 2003), in the second the observation period lasted 12 months (March 21, 2001 to March 19, 2002). Both studies performed observations and interviews with key-informants (significant subjects) and general informants. The outline employed in the first study was the phenomenological theory of expression and hermeneutic phenomenology. On the other hand, the second study was founded on Health Anthropology. Both studies followed Resolution n. ${ }^{\circ}$ 196/96 of the National Health Council. Moreover, informed consent was obtained from health institutions and informants, following the ethics code principles. Study projects were approved by the Institutional Review Board under numbers $12^{(7)}$ and $121 / 21^{(9)}$.

In order to present, interpret, and analyze the data, a guiding map or comparative plan was followed, approaching the following items: general characteristics of HIV-positive women/mothers and nurses at the rooming-in unit; description of the care context in which these women/mothers and workers live together; description of the approach between these women/ mothers and nurses; perceiving oneself as an HIV-positive women/mother; and the HIV-positive woman/mother from the nursing perspective.

\section{RESULTS}

The meaning of being an HIV-positive mother for HIV-positive postpartum women

From the subjects' descriptions regarding their experience and information obtained from field observation, it was possible to reveal the meaning that these women assign to being an HIV-positive mother. The obtained data were grouped and categorized in thematic units and essential themes. This provided a central meaning, understood as "One's self-perception of being a mother: I'm a supermom", and three other surrounding meanings: "defining what it means to be a good mother proud mother/supermom and protective mother "; recognizing changes brought about by child birth"; and "expressing feelings toward one's child and toward the condition of being a mother".

The central meaning “One's self-perception as being a mother: I'm a supermom" strongly reveals the privileged place that motherhood and maternal role have in the existence of the majority of postpartum women investigated. The motherhood experience generates a unique body image from the moment that the womanbeing becomes a mother-being. These transformations are expressed by means of understanding or perceiving themselves as mothers, seeking to establish a balanced relation with their own corporeality. The corporeality of motherhood-centered woman-beings activates a multiplicity of decisions and actions that are part of their own body, and involve different dimensions and moments of the reproductive cycle, from conception to pregnancy, delivery, and breast-feeding.

Beyond being a biological phenomenon, the process of transforming from woman-being into mother-being, for the study subjects, appears to be included in a broad network of meanings. Within this network, the goodmother idea is strongly present in the statements, and reflects the socially constructed models ${ }^{(11)}$. The supermom, also symbolically acknowledged as proud mother or the great mother, among other adjectives, appear as the idealized mother image. She is competent, and experienced in taking care of her child. She deposits her reason of being and existing in that child, obstinately and incessantly tracing the pathway for the child's fulfillment and happiness. She is caring, devoted, loving, balanced, calm, available, and happily performs all the tasks inherent to her mother role. This image is present in the postpartum women's statements, who express their perceptions of being mothers as: a great mother, proud mother, a supermom; over-protective mother, tenacious, always present, caring and devoted; patient, very considerate/ supportive, very happy/fulfilled, who educates and believes all mothers are this way; a sweet mother, who dislikes to spank her children, who establishes rules and limits; whose children are her first priority; and, is a real child as a mother; it is being their own mothers.

As it is described and understood, the mother-being is revealed, above all, as largely responsible for her child's development and wellbeing, devoting most of her time, i.e., centralizing her existence on this task. With rare exceptions, she is fully responsible for the integral and indispensable care her children need in order to grow and develop healthfully. They are also responsible for managing the daily tasks involving their everyday lives and their further existence, as illustrated in Aglaia's statement:

"[... I love my children passionately, but there's a limit to everything. We can't expect God to take care of everything. Will you go to school? [...] You will study. You will go to school, it is time for school, you have to study... You have to go to school, you have to do your homework, you have a curfew. I don't just simply let things happen alone. Not me. My 15-year-old son has to be home by nine o'clock. I don't let him stay out at ten o'clock, you know? There's a 
time to eat, a time do have breakfast; he gets up at seven-thirty and goes to school. My daughter goes to school at one-thirty in the afternoon; one studies in the morning and the other in the afternoon, you see? In the house, one does the dishes, the other sweeps the floor, one helps me clean the backyard; everyone has chores. I was pregnant with her and I couldn't do it all by myself. I have to work, I have to support them, I have to take care of them, and I still have to clean the house. They have to help. One does the dishes, one makes the beds, one sweeps the floor, and I do the laundry. That's how it is; everyone has his or her responsibilities. This is called responsibility. Because if I die they know how to cook beans, make rice, they know [...] they won't starve... Because my eighteen-year-old son got married, he's with the girl, but she can't even cook rice. He can cook beans, rice, meat, even pudding. I taught him all that. I did. He won't starve and neither will the other two. I'm here, but they get by, though they're at my oldest son's house, you know. I didn't leave them alone. Yesterday she came by to visit me and I said: daughter, go to school, just because mom's here doesn't mean you're quitting school. Go to school, and when I come home I want to see your notebooks. They have to be responsible, because I won't last forever" (Aglaia).

Concepts emerge from the meaning: "Defining what it means to be a good mother, a proud mother/ supermom and protective mother" regarding one who protects, gives affection, and cares for her child as much as possible, giving the child all he or she needs:

"[...] as a mother, I am a proud mother (smiles). To me, a proud mother is one who protects her child, gives affection, and care [...]" (Irina).

"I will be the best mother he could have. That means giving him everything. If I don't try to give him love, who will?" (Hebe).

"If I could, I would do what is possible and impossible, like... I think I would cross limits to give my children everything, you know? I would do anything, I think any mother would" (Eufrosina).

The meaning "Recognizing changes brought about by child birth" reveals that the motherhood experience poses important changes in women's ways of being and acting. Some even recall the figure of their own mothers and the mother/daughter connection.

"The love that we need the most isn't from a father, but from a mother. Because anyone can replace a father. I try to give her affection, but I can't. She won't let me. She said we don't like her. So I told her that if I didn't, I wouldn't, pregnant and all, rush to schedule a doctor's appointment for her, I wouldn't walk all the way to the health center to get her medication, you know? If I didn't like her, I wouldn't do all this. She doesn't recognize it. Like, I even gave her a pedicure before I checked in the hospital, Sunday night, so she would feel happier. [...]” (Aglaia).

"I thought: if my mom had given me the love I needed, I wouldn't be like this today, I guess [...] I think that, even though she was treated badly, she should have treated her children differently ... mothers only develop an appreciation for their children when they die or are at their worst. I've lived that, and I am still living it until today" (Hebe).

Hebe complains about the lack of maternal love, which she much needed and did not receive. She attributes her current circumstances to her mother. She talks about her mother with sorrow, in terms of the way she is treated by her mother, and for her reproducing the educational model that she also inherited from her own mother, often recollecting examples from her personal history. It was observed that, from her perspective, humans do not need paternal love, which she considers replaceable; what humans really need is mother's love. While she complains about the lack of maternal love, she tries to prove filial love, though unsuccessfully since it went by unnoticed by her mother, a fact she deeply regrets. Mother and daughter, daughter and mother, a relation that needs to be resolved. Based on her personal experience, she generalizes and extends to all mothers the concept that mothers only value their children when they die or are at their worst.

Different from Hebe, Leucothéa found in her mother figure a role model to be reproduced, valued, and respected.

"Being a mother, to me, is like being like my own mother (smiles). What my mother lived. I see that. That's it. Then I see, you know, we really should appreciate our mothers [...] mothers are everything. My mother is [...], she's my mother and my friend.... Despite the prejudice, because in the beginning she was really prejudiced against me, I never stopped loving her" (Leucothéa).

Finally, the meaning "Expressing feelings toward one's child and toward the condition of being a mother", appeared after several statements. These statements originated the expression of several feelings: love/adore her child; couldn't live without her child anymore; will be attached to her child, and her child to her; he/she is the love of her life; loves her child passionately; is very affectionate, is a real child; always thought of being a mother; is very happy as a mother, loves her children and lives for them, adores her children and likes the fact they are well, and refers to her child as a part of me [...].

"I guess I would no longer know how to live without him. Oh, I think I'll be really attached to him and be'll be really attached to me" (Agléia).

"Oh, for me it was [...] the moment I found out I would be a mother was a great happiness, you know? I always thought of being a mother [...] what it has been like? Oh, it's really great, he is the love of my life. I didn't expect this much. $\mathrm{Ob}$, and I hope it is always like this for me. I'm going to devote myself as much as I can to being a mother, I mean, I'm going to give love, a lot of 
attention, affection, and understand him, too. That's important. I'll surely be a proud mother. I'm really happy with him. He is the love of my life, a part of me" (Hybris).

The meaning of being an HIV-positive mother to nurses

Considering the universe of HIV-Positive women in rooming-in units, nurses usually refer to them as being "resistant". This establishes a sort of cultural framework, which, along with other cultural categories, like "the rebels" (postpartum women who, according to nurses, do not make efforts to learn how to care for themselves and for the newborn) and "the collaborative" (those who comply with institutional rules without questioning them), form a broad mosaic of women-mother types, in these nurses' cultural universe.

While "the rebels" are pointed out as those who largely disturb the usual work at the unit, "the resistant" are considered the most difficult to deal with. This is because they dissimulate and do not explicitly state their dissatisfaction or their degree of tolerance regarding the instructions they receive, or the lack of clarity in answers about health car. This makes it unclear if the professional advice that was given will be followed or not. These data permit to identify a subcategory of "resistance", comprising them as "Mothers with difficulties in being mothers", in view of their characteristics as "special" women in terms of the demands in health care and the social roles they must perform toward the newborn child. These women, compared to the majority of postpartum women who "collaborate", that is, comply with the unit and the regular postpartum process, are those who most stand out from the "ideal-type" of woman-mother, at least temporarily.

These meanings concern the difficulty to incorporate, with some skill, personal and child care. Nurses consider that the "women who have difficulties in being a mother" are always going through a delicate phase, either because they have some kind of physical impairment or because they are experiencing a unique relevant moment from an existential perspective, which assigns the "special" character to the representation. These "special" beings are strictly connected to the difficulties in performing their social roles as mothers. They have low self-esteem, body image disturbance, and social isolation.

"Did you see the one in [room] A-9? Did you see how angry she is for having that child? I don't know, don't you thinks it's irresponsible of her? And she doesn't even look at herself in the mirror, she has to be forced to take a shower and doesn't even care if her blouse has milk spots all over it. She'll have a hard time looking after her child, you can tell, right?" (Têmis-auxiliary nurse).

"Women with AIDS are usually lonely, it seems everyone moves away. I don't know, but I see that they don't take care of themselves, you know? They don't like themselves; it seems [...] this will eventually pass on to the child, right?" (Afrodite-nurse technician).

Also, nurses refer to "women with difficulties in being mothers" as those who cause the most stressful situations, followed by feelings of inability and incompetence to cope with care demands.

"She won't be able to manage that child!" (Têmis- auxiliary nurse).

"I'm sure this mommy is not capable of looking after her child" (Ananke-auxiliary nurse).

Besides these concerns, other meanings are attributed, with a strong moralist outline, somewhat stigmatizing. Interpreted from the light of the symbolic framework, they evidence a strong tendency to the normalization of the previous behaviors of the women who have just given birth, their affective and sexual relations, and their blame for having "decided" to be a mother, "despite" their knowing they carried the virus. The attribution of these meanings, like "she doesn't even care if her blouse has milk spots all over it", or, "the mommy in C-9 (HIV-positive postpartum woman) doesn't clean her child, ... she doesn't care about cleaning her" implies the apparent provocative "carelessness" of the postpartum women.

Another example regarding the attempt to moralize affective relationships appears when one of them verbalizes: "didn't she wonder if the guy had AIDS when they had sex?" Or in the expression: "poor baby, she's an angel and isn't guilty of anything ... the mother, I guess it's ok, you know? But the baby?" (emphasizing about a "resistant" mother". On the other hand, the 'irresponsibility' attributed to women is somewhat associated with a degree of "culpability", a result of the descontextualization from all the multiple factors that may have contributed to their being infected with HIV.

Some nurses consider "mothers with AIDS" as contaminated and, therefore, potential "contaminators". They believe the woman can "pass the virus by blood; we have to take all precautions to not get infected. Can you imagine? The blood is all contaminated". This evokes the institutional concern regarding the occupational risk of being infected with HIV, or the fact that there is a universal concern about swaddling women's breast to avoid infection of the child by the milk. These actions are suggestive of the potential of organic transmissibility, regarding biomedical principles.

Besides this type of contamination, nurses also have a representation of "symbolic contamination", resulting from the network of meanings they imply to HIV-Positive women, as shown in some statements: "she can contaminate her child, I don't know, hard to understand, isn't it? How can she be a mother, carrying the burden of this disease with her? And also: "should she stay around the others?" (statement of a nurse 
who, apparently, was fully competent of the technicaloperational technology regarding the risk of occupational HIV transmission). It appears that this idea of infection learned in the medical environment was extended to the understanding of postpartum women as a whole, including the cultural construction of the maternal role.

Stress is also given to the implemented rule that "breastfeeding is forbidden". For nurses, this sounds as something extremely serious, since they have the professional responsibility to avoid a possible transmission to the baby through mother's milk - an action that is impossible due to the mother's refusal to have her breasts swaddled (which is considered an appropriate clinical behavior). However, it appears that the greater fear is that, with their breasts exposed, "dropping milk on her blouse", women "might" breastfeed, and this would relieve nurses from their "responsibility", and transfer to the mother the "lack of responsibility" toward her child.

\section{DISCUSSION}

Regarding the meaning of being an HIV-positive mother for postpartum HIV-positive women, a central thematic unit emerges: "Perceiving oneself as a motherbeing: I am a supermom". This reveals that generally and independent from their age, education level, and occupation, the historically constructed idea that women are destined to motherhood, due to their biological nature, appears to remain not only untouched, but has also been strengthened. It is in the privacy of their homes, practicing their motherhood, that these women find their satisfaction and fulfillment of living in the world. The condition of being HIV-positive does not eliminate their pleasure of becoming a mother, and, perhaps due to the fact that they see, in their existential horizon, that their lives are threatened, they focus all their strength on their ability to generate life and on the art of caring for life. Motherhood is experienced as a strategy of deep personal fulfillment, of which comprehension appears to be difficult to apprehend. The possibility of motherhood strengthens their self-esteem while the miracle of life, the greatest expression of existence, challenges the dark mystery of disease and death, which continuously follows, torments, and threatens them.

These results are similar to those of three Brazilian studies $^{(12-14)}$. The first was developed in three reference STD and AIDS centers in the cities of Sao Paulo and Santos ${ }^{(12)}$. In the study, 1068 women living with HIV and AIDS were interviewed, and revealed their desire to become mothers as their fulfillment as women or of building a family ${ }^{(12)}$. The second study, conducted in Sao Carlos ${ }^{(13)}$ with HIV-positive pregnant women showed that, during their pregnancy, they held the belief that by having a child they would demonstrate "normality". They did not notice the threat to the child, as they would be valuing themselves by generating a new life. The meanings expressed by these women about their conditions as women and mothers reinforce the results of a third study $^{(14)}$, performed in the city of Sao Paulo. The study identified HIV-positive pregnant women's expectations and actions toward their pregnancy and their baby. Women who had had four to five previous pregnancies were pregnant once again, despite the risk of vertical transmission, because they believed that by following the treatment, they would give birth to a healthy non-infected baby. They compared themselves to any other healthy pregnant woman, considering that their only difference was the medication they took, since they felt well being pregnant $^{(15)}$.

The meanings "Defining what it means to be a good mother, proud mother/supermom and protectivemother" and "recognizing changes brought about by child birth", shed light on important components of initial relationships and the bonds established between mother/ daughter and their repercussions in the development of women's personalities, considering that the "character of the initial mother and child relationship deeply affects their sense of self, their further object relations, their feelings toward their own mothers and women in general"(16). On the other hand, the meaning denominated "Expressing feelings toward the child and toward the condition of being a mother" shows that maternal love and all its components appear as synonyms of a good mother, the main motherhood characteristic, and represents a support for establishing and strengthening mother and child attachment and bonds.

Maternal love, from the perspective of HIV-positive postpartum women in the present study, appears to be absorbed by a broader network of meanings. Motherhood, not only associated with the biological function of conceiving, procreating, reproducing, and generating life, but also articulated to a system of ideologically structures codes and values, stand out as a phenomenon linked to the cultural and social world, concerning actions that include caring, treating well, protecting, and educating.

In terms of the nurses' perception of the meaning of being and HIV-Positive mother, the collected data provide an array of representations. If nurses find that caring for the postpartum patient and the child at the same time is complex and challenging, a higher level of concern and coping difficulty is imposed when one of the characters in this setting is the HIV-positive postpartum patient.

If the universe of meanings that permeates the representation of "women with AIDS" is, per se, covered with conflicts and contradictions regarding health care, it is understood that, in the case of postpartum women, 
representations become even more nebulous and conflictive. This is because, for nurses, the motherhoodAIDS connection seems a dangerous combination that could yield serious problems in mother-child interactions. Therefore, these concerns include not only the perception of women who somehow try to overcome predictable social obstacles to "become a mother", but also the perception of "mother with AIDS", which denotes certain fragility, which is physical, social, and symbolic altogether. Hence, for nurses, if the "common" postpartum woman experiences a transitional, therefore insecure, period, which makes them vulnerable, "mothers with AIDS" have the burden of a double-meaning, that is, they have to doubly deal with their condition and vulnerability status.

Nurses" perception is that "mothers with AIDS" belong to a category of women who have difficulties in being mothers. Some previous studies have shown this perspective ${ }^{(17-19)}$, presenting interactive samples among nursing staff and AIDS patients. It was stated that contradictory feelings and confusing forms of relationships take place during health care, specifically due to the meanings assigned to caring for patients with AIDS. However, from these nurses' perspective, the difference or complement regarding HIV-positive postpartum women/mothers is, exactly, a specific type of "ambiguity" that is revealed when light is shed on the role built in the nurses' imaginary, considering the intersection between "women" with aids and "mothers with aids".

It is observed that the meeting point between these two symbols brings about the paradox that could be the basis for ambiguous feelings and the frequently conflictive health care actions performed at the unit. It is as if the fact of being HIV-positive does not "fit with" the experience of being a mother. Therefore, representations are contradictory. If, on one hand, the meaning of being an HIV-positive woman is connected to aspects of social stigma, indicating values often associated with danger, mystery, death, impurity, dirtiness, social promiscuity, and with attitudes that represent the "bad side" of the "good and virtuous women", like irresponsibility, weakness, and recklessness; on the other hand, new mothers need to learn quickly and perform their utmost role at this moment, since nurses consider immediate postpartum a highly sensitive period for developing maternal identity. Hence, they are considered women who need to be responsible, strong, sensible, and hold beliefs and values associated with purity, life, pride of being exposed to the eyes of society, and, with the symbol of virtue, provide the family with new life (giving birth).

These meaning networks, strongly connected to contrasts and bipolarities, can, in fact, affect nurses' feelings toward "mothers with AIDS" and lead to conflicts regarding the best way to provide educational health care to support postpartum women to perform their maternal role.

\section{CONCLUSION}

In summary, results show that for HIV-Positive women, they are "supermoms", whereas for nurses, they are "resistant". In other words, there is a nearly inverse representation regarding the same social phenomenon, in one same hospital setting. Nurses who care for this population in rooming-in state certain representations concerning the maternal role, which they consider absolutely incompatible with the condition of their being virus-carriers. Results show that, for these nurses, the fact that the postpartum women are HIV-Positive does not "fit with" the experience of being a mother. It is observed that these values, when contrasted with the perceptions of HIV-Positive women/mothers in this study, are evidently impregnated with prejudice and social stigma. Moreover, they are far from taking into consideration the maternal feelings of HIV-Positive women/mothers.

This modal idea resulting from the comparison of the representations from nurses' and postpartum women's perspectives also includes a derivation in terms of the condition of being considered "special" women. For postpartum women, being a "supermom" is special, in the sense of being a "good mother", "proud mother" or "protective mother". On the other hand, for nurses, this "special" condition refers to being "mothers with AIDS", which implies that being an HIV-Positive woman means having difficulties in being a mother. These difficulties have two meanings. The first, a positive one, refers to the representation in which these women, from the nurses' perspective, are connected to the idea of vulnerability, having little or no self-esteem, and tendencies to social isolation. The second, and negative, identifies these women from a moralist and stigmatizing outline. Hence, the meaning of being "mothers with AIDS", to nurses, originates (and causes) two types of "contamination", pathogenic (regarding viral reactions in the body), and symbolic (in terms of the social roles performed by women and mainly associated with the "inadvertent" practice of motherhood).

The present study results could help to understand the institutionalization processes of this specific population. In addition, nursing and health personnel could improve and recognize HIV-positive women/mothers as citizens who also have rights, individual and social, and thus contribute to extinguishing the stigma, prejudice and/or social discrimination, with a view to humanizing health care.

\section{REFERENCES}

1. United Nations Programme on HIV/Aids, Organização 
Mundial da Saúde. Relatório mundial sobre a situação da epidemia da aids no mundo. Nova Delhi; UNAIDS/OMS: 2005.

2. Brasil. Ministério da saúde. Secretaria de Vigilância em Saúde. Programa Nacional de DST e Aids. $1^{\text {a }}$ à $26^{a}$ semanas epidemiológicas - janeiro a junho de 2006. Bol Epidemiol Aids e DST. 2006; 3 (1): 4-11.

3. Governo do Estado de Santa Catarina. Secretaria de Estado da Saúde. DIVE - Diretoria de Vigilância Epidemiológica. Gerência de DST e Aids [sítio na Internet]. Situação da epidemiologia de aids em Santa Catarina. [citado 2007 Jan 9]. Disponível em http://www.dive.sc.gov.br.

4. Mandú ENT. Critérios e indicadores de qualidade da atenção à saúde da mulher. Rev Gaúch Enferm. 2005; 26(1): 11-9.

5. Coelho DF, Motta MGC. A compreensão do mundo vivido pelas gestantes portadoras do vírus da imunodeficiência humana (HIV). Rev Gaúch Enferm. 2005; 26(1): 31-41.

6. Paiva SS, Galvão MTG. Sentimentos diante da não amamentação de gestantes e puérperas soropositivas para HIV. Texto \& Contexto Enfermagem. 2004; 13(3): 414-9.

7. Santos EKA. A expressividade corporal do ser-mulher/mãe HIV positiva frente à privação do ato de amamentar: a compreensão do significado pela enfermeira à luz da teoria da expressão de Merleau-Ponty [tese]. Florianópolis: Programa de Pós-Graduação em Enfermagem, Centro Ciências da Saúde, Universidade Federal de Santa Catarina; 2004.

8. Pereira MLD, Chaves EC. Ser mãe e estar com aids: o revivescimento do pecado original. Rev Esc Enfermagem USP. 1999; 33(4): 404-10.

9. Monticelli M. Aproximações culturais entre trabalhadoras de enfermagem e famílias, no contexto do nascimento hospitalar: uma etnografia de alojamento conjunto [tese].
Florianópolis: Programa de Pós-Graduação em Enfermagem, Universidade Federal de Santa Catarina; 2003.

10. Maggs-Rapport F. Combining methodological approaches in research: ethnography and interpretative phenomenology. J Adv Nurs. 2000; 31(1); 219-25.

11. Monteiro JCS, Gomes FA, Nakano AMS. Percepção das mulheres acerca do contato precoce e da amamentação em sala de parto. Acta Paul Enfermagem. 2006; 19(4): 427-32.

12. Paiva V, Latorre MR, Gravato N, Lacerda R. Sexualidade de mulheres vivendo com HIV/AIDS em São Paulo. Cad Saúde Pública = Rep Public Health. 2002; 18(6): 1609-20.

13. Ruggiero EMS. Gestante portadora do vírus HIV - vida e significado [tese]. Ribeirão Preto: Escola de Enfermagem da Universidade de São Paulo; 2000.

14. Moura EL, Praça NS. Transmissão vertical do HIV: expectativas e ações da gestante soropositiva. Rev Latinoam Enfermagem. 2006; 14(3):405-12.

15. Parker R. Perigo no casamento. Entrevista concedida a Mônica Manir. Estado de São Paulo [jornal na Internet]. São Paulo; 5 Dez 2005. [citado 2006 Out 20]. Disponível em: http://www.abiaids.org.br

16. Chodorow N. Psicanálise da maternidade: uma crítica a Freud a partir da mulher. Rio de Janeiro: Rosa dos Tempos; 1990.

17. Jirapaet V. Factors affecting maternal role attainment among low-income, Thai, HIV-positive mothers. J Transcult Nurs. 2001; 12(1): 25-53.

18. Sadala MLA, Matias LO. Os significados atribuídos ao cuidar de pacientes com AIDS. Rev Esc Enfermagem USP. 2000; 34(1): 1-8.

19. Giami A, Veil C. Enfermeiras frente à AIDS: representações e condutas, permanência e mudanças. Canoas: Ulbra; 1997. [Coleção Análise e Prospectiva] 